\title{
БИОЛОГИЧЕСКАЯ АКТИВНОСТЬ БЕНЗАННЕЛИРОВАННЫХ МАКРОЦИКЛИЧЕСКИХ ТРИПЕРОКСИДОВ
}

\author{
И.Р. Ишмухаметова, Н.Н. Махмудиярова, А.Г. Ибрагимов, \\ Л.У. Джемилева, В.А. Дьяконов, У.М. Джемилев \\ Институт нефтехимии и катализа УФИЦ РАН, \\ 450075, Россия, Республика Башкортостан, г. Уфа, пр. Октября, 141.
}

DOI: 10.19163/MedChemRussia2021-2021-503

E-mail: iuliania93@mail.ru

Учитывая высокий потенциал использования пероксидов в качестве основы для разработки новых противоопухолевых препаратов, для ранее неописанных синтезированных нами бензаннелированных 13- и 14-членных макроциклических трипероксидов нами проведены исследования по изучению их цитотоксической активности in vitro в отношении опухолевых культур Jurkat, K562, U937 и нормальной клеточной линии Fibroblasts.

\begin{tabular}{|l|l|l|l|l|}
\hline Соединение & $\begin{array}{c}\text { Jurkat } \\
(\mathrm{IC} 50, \mu \mathrm{M})\end{array}$ & $\begin{array}{c}\mathrm{K} 562 \\
(\mathrm{IC} 50, \mu \mathrm{M})\end{array}$ & $\begin{array}{c}\text { U937 } \\
(\mathrm{IC} 50, \mu \mathrm{M})\end{array}$ & $\begin{array}{c}\text { Fibroblasts } \\
\text { (IC50, } \mu \mathrm{M})\end{array}$ \\
\hline $3.17 \pm 0.24$ & $10.11 \pm 0.97$ & $7.32 \pm 0.54$ & $127.23 \pm 9.67$ \\
\hline
\end{tabular}

Соединения, приведенные в таблице, проявили наибольшую активность в отношении выбранных опухолевых клеточных линий. При этом симметричный пероксид 3 показал существенно меньшую цитотоксичность по сравнению с несимметричным пероксидом 2 с аналогичными метилциклогексановыми заместителями.

$$
-503-
$$

